\title{
Faktor Apa yang Mempengaruhi Rendahnya Tingkat Pengobatan Tuberkulosis di Lagoa Jakarta?
}

\author{
Althaf Dhaifullah Nurhakim, Mashoedojo, Erna Harfiani \\ Program Studi S1 Kedokteran, Fakultas Kedokteran, Universitas Pembangunan Veteran \\ Jakarta
}

\begin{abstract}
Abstrak
Latar belakang: Penyakit tuberkulosis merupakan penyakit menular dengan penyebab bakteri Mycobacterium tuberculosis. Penyakit ini dapat mengenai segala usia dan mempengaruhi semua organ Organ yang sering diserang yaitu paru-paru. Pada tahun 2016, dilakukan upaya pengobatan terhadap 55.503 pasien TB paru BTA positif di DKI Jakarta, dengan tingkat keberhasilan pengobatan terendah ditemukan di Jakarta Utara (3,99\%). Oleh karena itu, penelitian ini ditujukan untuk mendapatkan faktor yang mempengaruhi rendahnya tingkat keberhasilan pengobatan TB paru di Puskesmas Lagoa.

Metode: Penelitian ini menggunakan metode cross-sectional dan purposive sampling dengan sampel merupakan pasien dengan tuberkulosis paru yang telah menjalani perawatan lengkap di Puskesmas Lagoa di Jakarta Utara sebanyak 64 orang secara total sampling tahun 2017. Data diambil menggunakan kuesioner yang sudah divalidasi. Sampel merupakan pasien dengan riwayat pengobatan TB paru di Puskesmas Lagoa, berusia minimal 15 tahun, telah menyelesaikan program pengobatan selama 6 bulan di Puskesmas Lagoa, TB paru yang tinggal di wilayah kerja dari Puskesmas Lagoa. Data dianalisis menggunakan regresi logistik

Hasil: Ditemukan hubungan yang signifikan antara usia, jenis kelamin, ketersediaan obat, dukungan supervisor pengobatan, dan dukungan petugas terhadap tingkat keberhasilan pengobatan penyakit TB $(O R=7,031 ; 95 \%$ CI 1.051-47.018).

Kesimpulan: Faktor yang mempengaruhi rendahnya tingkat pengobatan penyakit TB paru adalah usia, jenis kelamin, ketersediaan obat, dukungan supervisor dan dukungan petugas dengan jenis kelamin sebagai faktor yang paling signifikan di Puskesmas Lagoa pada 2017.
\end{abstract}

Kata kunci: Jenis kelamin, Pengobatan, Tingkat keberhasilan, Tuberkulosis

\section{What Factors Affect Low Rates of Tuberculosis Treatment in Lagoa Jakarta?}

\begin{abstract}
Background: Tuberculosis is an infectious disease with the cause of mycobacterium tuberculosis bacteria. This disease can affect all ages and affect all organs which the lungs are the most infected organ. In 2016, treatment efforts were made against 55,503 positive BTA pulmonary TB patients in DKI Jakarta, with the lowest treatment success rate found in North Jakarta (3.99\%). Therefore, this research is aimed at obtaining factors that affect the low success rate of pulmonary TB treatment in Lagoa Health Center.

Methods: This study used a cross-sectional method and purposive sampling with a sample of 64 patients with pulmonary tuberculosis who had undergone complete treatment at the Lagoa Public Health Center in North Jakarta in 2017. Data were taken using a validated questionnaire. Sample were patients with a history of pulmonary TB treatment at Puskesmas Lagoa, aged at least 15 years, had completed a 6 month treatment program at Lagoa Health Center, pulmonary TB living in the working area of Lagoa Health Center. Data analyzed using logistic regression

Results: There was a significant relationship between age, sex, drug availability, treatment supervisor support, and staff support to the success rate of TB treatment (OR $=7.031 ; 95 \%$ CI 1.051-47.018).

Conclusion: Factors affecting low rates of treatment of pulmonary TB are age, gender, drugs availability, supervisor support and support of officers. Gender is the most significant factors at Lagoa Health Center in 2017.

Keywords: Gender, Treatment, Success rate, Tuberculosis

\author{
Alamat korespondensi: \\ Erna Harfiani \\ Universitas Pembangunan Nasional Veteran Jakarta \\ Jl. RS Fatmawati, Pondok Labu \\ Email: ernaharfiani@upnvj.ac.id
}




\section{PENDAHULUAN}

Penyakit tuberkulosis merupakan penyakit menular dengan penyebab bakteri Mycobacterium tuberculosis. Tuberkulosis dapat mengenai siapa saja dan mengenai seluruh organ tubuh manusia. Diperkirakan sampai sekitar satu per tiga penduduk di dunia diduga telah terinfeksi Mycobacterium tuberculosis. Pada tahun 2014, tercatat angka prevalensi Tuberkulosis mencapai 647/100.000 penduduk, jumlah ini meningkat dari 272/100.000 penduduk dibandingkan tahun yang lalu, dengan angka mortalitas tahun 2014 mencapai 41/100.000 penduduk. $^{1}$ Dilihat dari kondisi tersebut, diperlukan upaya program penanggulangan untuk penyakit Tuberkulosis. Program Pemberantasan Tuberkulosis telah terus dilakukan secara bertahap di Pusat Kesehatan Masyarakat (Puskesmas) dengan melakukan penerapan strategi Directly Observed Treatment Shortcourse (DOTS), yang direkomendasikan oleh WHO sejak tahun 1995. Lima komponen yang terdapat dalam strategi DOTS meliputi, komitmen politis dari pemerintah dalam menjalankan program tuberkulosis nasional, diagnosis tuberkulosis melalui pemeriksaan dahak dengan cara mikroskopis, pengobatan tuberkulosis dengan panduan Obat Anti Tuberkulosis (OAT) dengan pengawasan Pengawas Minum Obat (PMO), menjaga kesinambungan persediaan obat, pencatatan dan pelaporan dalam memudahkan pemantauan dan menjalankan evaluasi program penanggulangan dari penyakit tuberkulosis paru. ${ }^{2}$

Sejak tahun 2016 telah ditingkatkan upaya pengobatan terhadap 55.503 penderita tuberkulosis paru Basil Tahan Asam atau BTA+ di DKI Jakarta, dengan hasil angka keberhasilan terbesar adalah di wilayah Jakarta Barat, yaitu sebesar 83,24\% sedangkan angka keberhasilan pengobatan yang paling rendah terdapat di wilayah Jakarta Utara 3,99\%. Hasil yang didapat disebabkan oleh beberapa faktor yang mempengaruhi keberhasilan pengobatan, yang paling utama adalah kesadaran masyarakat dalam rangka melakukan pengobatan secara teratur dan disiplin, serta pemantauan dan evaluasi dari petugas kesehatan (Lagoa, 2017). ${ }^{3}$

Kota Jakarta Utara terdiri dari 6 kecamatan dengan 32 kelurahan, dimana
Kelurahan Lagoa merupakan salah satunya yang memiliki fasilitas kesehatan berupa puskesmas dengan luas wilayah seluas 157.99 Ha terbagi dalam 18 Rukun Warga (RW) dan 222 Rukun Tetangga 0 (RT). Rendahnya angka keberhasilan pengobatan tuberkulosis paru, khususnya di Kotamadya Jakarta Utara menjadi salah satu masalah yang sangat kompleks, mengingat tuberkulosis masih merupakan infeksi yang penularannya mudah dan cepat. ${ }^{4}$ Oleh karena itu, penelitian ini ditujukan untuk mendapatkan faktor yang mempengaruhi rendahnya tingkat keberhasilan pengobatan $\mathrm{TB}$ paru di Puskesmas Lagoa

\section{METODE}

Penelitian ini menggunakan metode cross sectional dan pengambilan data secara purposive sampling. Populasi yang terlibat di penelitian ini merupakan penderita tuberkulosis paru yang telah menjalani pengobatan lengkap di Puskesmas Kelurahan Lagoa Jakarta Utara pada periode tahun 2017. Sampel penelitian sebanyak 64 pasien yang berobat di Puskesmas Kelurahan Lagoa pada tahun 2017 yang memenuhi kriteria memiliki riwayat pengobatan TB paru di Puskesmas Lagoa, berusia minimal 15 tahun, telah menyelesaikan program pengobatan selama 6 bulan di Puskesmas Lagoa, TB paru yang tinggal di wilayah kerja dari Puskesmas Lagoa. ${ }^{4}$

Data primer dan sekunder digunakan dalam penelitian ini. Status pasien didapat dari rekam medis pasien yang bersangkutan yang sudah tercatat di Puskesmas Lagoa. Pada sumber data tersebut, diketahui terdapat 134 pasien yang telah selesai menjalani pengobatan TB paru secara lengkap selama 6 bulan dan terpilih sampel yang memenuhi syarat sebanyak 64 orang. Subjek terpilih merupakan pasien yang mendatangi puskesmas dan memenuhi dari kriteria pemilihan yang telah ditetapkan dimasukkan pada penelitian sampai mencapai jumlah subjek terpenuhi kemudian dilakukan analisis data. Data primer diambil melalui kuesioner Evaluasi Kepatuhan Berobat Penderita Tuberkulosis Paru yang dibuat oleh Hayati yang sudah diuji validitas dan reliabilitasnya untuk membantu penilaian faktor-faktor yang dapat mempengaruhi tingkat keberhasilan pengobatan TB paru. Sedangkan data sekunder diambil dari 
data rekam medis pasien TB paru di Puskesmas Kelurahan Lagoa, Jakarta Utara. ${ }^{5}$ Data dianalisis menggunakan regresi logistic dengan signifikansi $5 \%$.

\section{HASIL}

\section{Karakteristik Distribusi Responden}

\section{Tabel 1. Karakteristik Pasien TB Paru} di Puskesmas Lagoa, 2017

\begin{tabular}{|c|c|c|}
\hline Karakteristik & $\begin{array}{l}\text { Jumlah } \\
\text { (n) }\end{array}$ & $\begin{array}{l}\text { Persentase } \\
(\%)\end{array}$ \\
\hline \multicolumn{3}{|l|}{ Jenis Kelamin } \\
\hline 1. Laki-laki & 38 & 59,4 \\
\hline 2. Perempuan & 26 & 40,6 \\
\hline \multicolumn{3}{|l|}{ Usia } \\
\hline 1. 15 sampai $24 \mathrm{Th}$ & 12 & 18,8 \\
\hline 2. 25 sampai $34 \mathrm{Th}$ & 15 & 23,4 \\
\hline 3. 35 sampai $44 \mathrm{Th}$ & 12 & 18,8 \\
\hline 4. 45 sampai $54 \mathrm{Th}$ & 15 & 23,4 \\
\hline 5. $\geq 55 \mathrm{Th}$ & 10 & 15,6 \\
\hline \multicolumn{3}{|l|}{ Pendidikan } \\
\hline 1. Tidak Sekolah & 4 & 6,3 \\
\hline 2. Setingkat SD & 25 & 39,1 \\
\hline 3. Setingkat SMP & 18 & 28,1 \\
\hline 4. Setingkat SMA & 16 & 25,0 \\
\hline $\begin{array}{l}\text { 5. Setingkat } \\
\text { Diploma3,Sarjana } \\
\text { S1,S2,S3 }\end{array}$ & 1 & 1,6 \\
\hline \multicolumn{3}{|l|}{ Pekerjaan } \\
\hline 1. Tidak Bekerja & 13 & 20,3 \\
\hline 2. Pelajar/Mahasiswa & 3 & 4,7 \\
\hline 3. Pegawai & 6 & 9,4 \\
\hline 4. Wirausaha & 6 & 9,4 \\
\hline 5. Ibu Rumah Tangga & 16 & 25,4 \\
\hline 6. Lain-lain & 20 & 31,3 \\
\hline \multicolumn{3}{|l|}{$\begin{array}{l}\text { Jumlah Pendapatan Keluarga } \\
\text { /bulan }\end{array}$} \\
\hline 1. $<\mathrm{Rp} 1.000 .000$ & 44 & 68,8 \\
\hline $\begin{aligned} 2 . & \geq \mathrm{Rp} 1.000 .000- \\
& <\mathrm{Rp} 2.000 .000\end{aligned}$ & 14 & 21,9 \\
\hline $\begin{aligned} \text { 3. } \geq \operatorname{Rp} 2.000 .000- \\
<\mathrm{Rp} 4.000 .000\end{aligned}$ & 5 & 7,8 \\
\hline 4. $\geq \mathrm{Rp} 4.000 .000$ & 1 & 1,6 \\
\hline
\end{tabular}

Sebaran pasien TB paru terbanyak berada pada rentang usia 25 sampai 34 tahun dan 45 sampai 54 tahun dengan jumlah pasien yang sama yaitu 15 orang $(23,4 \%)$. Mayoritas pasien hanya menyelesaikan pendidikan SD sebanyak 25 orang $(39,1 \%)$. Berdasarkan pekerjaan, mayoritas pasien TB paru di Puskesmas Lagoa bekerja sebagai pelaut, yang diisi dengan opsi lain-lain pada kuesioner penelitian yakni sebanyak 20 orang $(31,3 \%)$. Jumlah pendapatan dari keluarga per bulan pada pasien TB paru di Puskesmas Lagoa diketahui mayoritas <Rp1.000.000 dengan jumlah 44 orang $(68,8 \%)$ (Tabel 1).

Berdasarkan data sekunder, diketahui mayoritas pasien belum mencapai kesembuhan dengan jumlah 51 orang $(79,7 \%)$, dengan pasien yang telah sembuh setelah menjalani pengobatan TB paru hanya berjumlah 13 orang $(20,3 \%)$. Pada aspek ketersediaan obat, mayoritas pasien memilih opsi selalu tersedia dengan jumlah 44 orang $(68,8 \%)$. Persentase perilaku dukungan PMO terhadap pasien TB paru secara mayoritas adalah cukup mendukung sebanyak 25 orang $(39,1 \%)$. Persentase pasien yang menyatakan bahwa mayoritas petugas TB bersikap mendukung sebesar 50\% (Gambar 1).

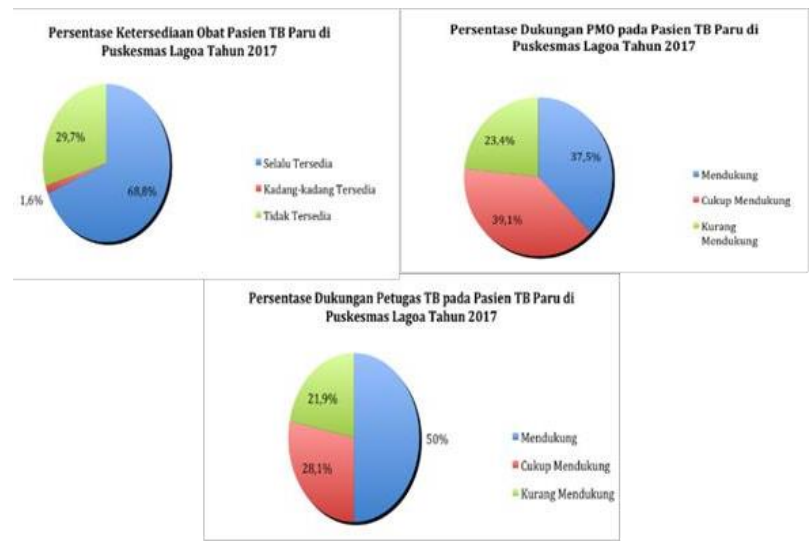

Gambar 1. Persentase Ketersediaan Obat, dukungan PMO dan dukungan petugas TB pada pasien TB paru di PKM Lagoa, 2017

Hubungan antara Usia, Jenis Kelamin, Ketersediaan obat, Dukungan supervisor dan Dukungan petugas TB dengan Rendahnya Angka Keberhasilan Pengobatan TB Paru

Distribusi antara usia, jenis kelamin, ketersediaan obat, dukungan supervisor dan dukungan petugas TB dengan rendahnya angka keberhasilan pengobatan TB paru disajikan pada Tabel 2. Selanjutnya dilakukan analisis untuk mengetahui bagaimana hubungan antara usia dengan rendahnya angka keberhasilan TB Paru. Hasil uji Chi Square didapatkan data nilai dari $\mathrm{p}$ $=0,469$. Karena $\mathrm{p}>0,05$, sehingga dapat diambil kesimpulan bahwa tidak terdapat hubungan signifikan antara usia dengan rendahnya angka keberhasilan TB Paru. 
Tabel 2. Hubungan antara Usia, Jenis kelamin, Ketersediaan obat, Dukungan PMO dan Dukungan petugas TB dengan Rendahnya Angka Keberhasilan Pengobatan TB Paru

\begin{tabular}{|c|c|c|c|c|c|c|}
\hline \multirow{3}{*}{ Variabel } & \multicolumn{6}{|c|}{ Status Pasien } \\
\hline & \multicolumn{2}{|c|}{ Tidak Sembuh } & \multicolumn{2}{|c|}{ Sembuh } & \multicolumn{2}{|c|}{ Total } \\
\hline & $\mathbf{N}$ & $\%$ & $\mathbf{N}$ & $\%$ & $\mathbf{N}$ & $\%$ \\
\hline \multicolumn{7}{|l|}{ Usia } \\
\hline 15 sampai $24 \mathrm{Th}$ & 9 & 75 & 3 & 25 & 12 & 100 \\
\hline 25 sampai $34 \mathrm{Th}$ & 14 & 92,3 & 1 & 6,7 & 15 & 100 \\
\hline 35 sampai $44 \mathrm{Th}$ & 10 & 83,3 & 2 & 16,7 & 12 & 100 \\
\hline 45 sampai $54 \mathrm{Th}$ & 10 & 66,7 & 5 & 33,3 & 15 & 100 \\
\hline$>55 \mathrm{Th}$ & 8 & 80 & 2 & 20 & 10 & 100 \\
\hline \multicolumn{7}{|l|}{ Jenis Kelamin } \\
\hline Laki laki & 27 & 71,1 & 11 & 28,9 & 38 & 100 \\
\hline Perempuan & 24 & 92,3 & 2 & 7,7 & 26 & 100 \\
\hline \multicolumn{7}{|l|}{ Ketersediaan Obat } \\
\hline Selalu tersedia & 31 & 70,5 & 13 & 29,5 & 44 & 100 \\
\hline Kadang Tersedia & 19 & 100 & 0 & 0 & 19 & 100 \\
\hline Tidak tesedia & 1 & 100 & 0 & 0 & 1 & 100 \\
\hline \multicolumn{7}{|l|}{ Dukungan PMO } \\
\hline Mendukung & 14 & 58,3 & 10 & 41,7 & 24 & 100 \\
\hline Cukup mendukung & 22 & 88 & 3 & 12 & 25 & 100 \\
\hline Kurang mendukung & 15 & 29,4 & 0 & 0 & 15 & 100 \\
\hline \multicolumn{7}{|l|}{ Dukungan Petugas TB } \\
\hline Mendukung & 21 & 65,6 & 11 & 34,4 & 32 & 100 \\
\hline Cukup mendukung & 16 & 88,9 & 2 & 11,1 & 18 & 100 \\
\hline Kurang mendukung & 14 & 100 & 0 & 0 & 14 & 100 \\
\hline
\end{tabular}

Untuk hubungan antara jenis kelamin terhadap rendahnya angka keberhasilan pengobatan TB paru menunjukkan bahwa hasil uji ChiSquare didapatkan data nilai dari $\mathrm{p}=$ 0,038 sehingga disimpulkan terdapat hubungan antara jenis kelamin dengan rendahnya angka keberhasilan pengobatan TB paru. Terdapat hubungan jenis kelamin dan rendahnya angka keberhasilan TB Paru $(\mathrm{p}=0,025)$. Ditemukan adanya hubungan antara dukungan PMO dengan rendahnya angka keberhasilan TB Paru $(\mathrm{p}=0,003)$. Jenis kelamin juga ditemukan signifikan terhadap rendahnya angka keberhasilan pengobatan TB paru $(\mathrm{p}=0,015)$.

Selanjutnya dilakukan analisis multivariat pada penelitian ini dengan menggunakan uji regresi logistik untuk mengetahui hubungan antara seluruh variabel bebas yaitu jenis kelamin, usia, dukungan PMO, dukungan petugas $\mathrm{TB}$, serta ketersediaan obat dengan variabel terikat yaitu rendahnya angka keberhasilan TB Paru. Pada hasil uji kesesuaian model dengan menggunakan uji Hosmer and Lemeshow didapatkan nilai $\mathrm{p}=0,999$ lebih besar dari pada taraf signifikansi $\alpha=0,05(\mathrm{p}>0,05)$. 
Kemudian, dilakukan uji regresi logistik dan didapatkan hasil bahwa sebaran jenis kelamin merupakan variabel independen yang memiliki hubungan paling signifikan terhadap angka keberhasilan pengobatan TB paru, di mana sebaran jenis kelamin memiliki nilai Odds Ratio $=7.031$ yang berarti sebaran jenis kelamin memiliki hubungan yang lebih besar sebanyak 7.31 kali dalam mempengaruhi angka keberhasilan pengobatan TB paru (Tabel 3).

Tabel 3. Uji Regresi Logistik Faktor yang Paling Berpengaruh terhadap Rendahnya Angka Keberhasilan Pengobatan TB Paru

\begin{tabular}{|c|c|c|c|c|c|c|c|c|}
\hline & \multirow[t]{2}{*}{ B } & \multirow[t]{2}{*}{ S.E. } & \multirow[t]{2}{*}{ Wald } & \multirow[t]{2}{*}{ Df } & \multirow[t]{2}{*}{ Sig. } & \multirow[t]{2}{*}{$\begin{array}{l}\text { Odds } \\
\text { Ratio }\end{array}$} & \multicolumn{2}{|c|}{$\begin{array}{l}\text { 95\% C.I.for } \\
\text { EXP(B) }\end{array}$} \\
\hline & & & & & & & Lower & Upper \\
\hline - Jenis Kelamin & 1.950 & .970 & 4.047 & 1 & .044 & 7.031 & 1.051 & 47.018 \\
\hline - Usia & .226 & .314 & .515 & 1 & .473 & 1.253 & .677 & 2.320 \\
\hline $\begin{array}{l}\text {-Ketersediann } \\
\text { Obat }\end{array}$ & -20.499 & $\begin{array}{r}7330 . \\
359\end{array}$ & .000 & 1 & .998 & .000 & .000 & . \\
\hline $\begin{array}{l}\text {-Dukungan } \\
\text { PMO }\end{array}$ & -1.212 & .815 & 2.211 & 1 & .137 & .298 & .060 & 1.470 \\
\hline $\begin{array}{l}\text {-Dukungan } \\
\text { Petugas TB }\end{array}$ & -1.409 & .814 & 2.999 & 1 & .083 & .244 & .050 & 1.204 \\
\hline Constant & 21.584 & $\begin{array}{r}7330 . \\
359\end{array}$ & .000 & 1 & .998 & $\begin{array}{r}236380 \\
5676.9 \\
85 \\
\end{array}$ & & \\
\hline
\end{tabular}

\section{PEMBAHASAN}

Penelitian ini menemukan tidak terdapat hubungan signifikan antara usia dengan rendahnya angka keberhasilan TB Paru. Hasil yang sama didapatkan pada penelitian Maulidya dan Hayati, bahwa tidak adanya hubungan yang bermakna antara usia dengan angka keberhasilan pengobatan TB paru. Hasil dari penelitian ini menunjukkan bahwa usia bukanlah satu-satunya alasan atau faktor yang berpengaruh dalam keberhasilan pengobatan pasien TB paru, sehingga dapat disimpulkan bahwa berapapun usianya, setiap pasien tetap mempunyai kesempatan untuk sembuh jika didukung oleh faktor-faktor lainnya. ${ }^{5,6}$ Hasil analisis hubungan antara jenis kelamin terhadap rendahnya angka keberhasilan TB paru yang didapat tidak sejalan dengan penelitian yang dilaksanakan oleh Harnanik di Grobogan. ${ }^{7}$

Ditemukan hasil yang konsisten dengan penelitian yang dilaksanakan oleh Hasan dan Prayogo yang menyatakan bahwa terdapat pengaruh signifikan antara ketersediaan obat terhadap keberhasilan pengobatan TB paru. Adanya hubungan yang bermakna antara ketersediaan obat dengan angka keberhasilan pengobatan TB paru menunjukkan pentingnya peran Puskesmas dalam menyediakan Obat Anti Tuberkulosis (OAT) untuk menunjang kesembuhan pasien TB paru. Hal ini dapat terlihat dari hasil penelitian yang menunjukan seluruh pasien yang menjawab opsi tidak tersedia dan kadang-kadang tersedia belum mencapai kesembuhan ${ }^{8,9}$

PMO (Pengawas Minum Obat) merupakan salah satu komponen DOTS (Directly Observed Treatment Shortcourse) untuk menjamin keteraturan pengobatan pasien TB Paru. ${ }^{10}$ Hasil penelitian ini membuktikan bahwa sangat diperlukan dukungan PMO dalam menjamin agar pasien TB paru menyelesaikan seluruh masa pengobatan hingga tuntas. Dengan adanya bantuan PMO, jumlah orang yang menghentikan pengoboatan dapat ditekan sampai $5 \%$ atau bahkan lebih.

Jenis kelamin juga ditemukan dengan rendahnya angka keberhasilan pengobatan TB paru. Hasil ini sejalan dengan penelitian oleh Hasan di Sumatera Utara yang melaporkan bahwa terdapat pengaruh signifikan antara sikap petugas TB terhadap keberhasilan 
pengobatan TB paru di Puskesmas Semula. Jadi setiap pasien TB paru yang datang untuk berobat ke Puskesmas akan mendapatkan pelayanan (sikap/tindakan/ penyuluhan) kesehatan yang sama dari petugas TB di puskesmas, tetapi tingkat kepuasan dari pasien atas pelayanan tersebut tidaklah selalu sama diantara pasien satu dengan lainnya. ${ }^{8}$ Hasil penelitian ini menunjukkan mayoritas pasien TB paru adalah laki-laki dan sesuai dengan distribusi kejadian penyakit TB paru di Negara Indonesia diderita oleh sebagian besar laki-laki menurut Riskesdas 2013. ${ }^{11}$ Tuberkulosis paru lebih dominan menyerang laki-laki bila dibandingkan dengan perempuan karena sebagian besar laki-laki berkebiasaan merokok yang memudahkan terjangkitnya penyakit TB paru.

Hal ini sejalan dengan penelitian yang dilaksanakan oleh Sudiantara di NTB yang melaporkan kasus paling banyak terjadi pada kelompok usia 11 sampai 55 tahun. ${ }^{12}$ Hasil penelitian ini juga sejalan dengan pernyataan dari Kemenkes Republik Indonesia bahwa sekitar $75 \%$ penderita penyakit TB paru merupakan kelompok umur produktif yaitu 15 sampai 50 tahun. ${ }^{10}$ Pada penelitian ini, ditemukan mayoritas pasien laki-laki bekerja sebagai pelaut dan tinggal di wilayah padat penduduk. Hal tersebut dapat menjadi faktor risiko dari lingkungan rumah yang lembab dan minim ventilasi serta lingkungan pekerjaan yang dapat meningkatkan angka penyebaran TB Paru. Selain itu, beberapa pasien menuturkan adanya kebiasaan merokok ataupun terpapar asap rokok yang dapat memicu terjadinya TB Paru. Pekerjaan sebagai pelaut juga membuat beberapa pasien merasa sedikit kesulitan untuk dapat menjalani pengobatan secara teratur sehingga setelah dilakukan pemeriksaan dahak, didapatkan hasil BTA positif yang menandakan pengobatan masih dalam kategori gagal. Hasil penelitian ini sesuai dengan penelitian yang dilaksanakan oleh Rushadi dkk di Kota Sukabumi dengan temuan bahwa variabel jenis kelamin laki-laki lebih berisiko 7,283 kali lebih besar untuk menderita TB paru. ${ }^{13}$ Begitu pula penelitian oleh Rukmini dan Chatarina menemukan laki-laki lebih berisiko 1,6 kali menderita TB paru dibandingkan wanita. ${ }^{14}$ Namun, berbeda dengan hasil penelitian Azizah dan Inayah bahwa ketersediaan OAT lebih berpengaruh terhadap terjadinya TB Paru. ${ }^{15}$

Ketersediaan obat juga mempengaruhi rendahnya tingkat pengobatan penderita tuberkulosis paru di wilayah Lagoa. Pada penelitian ini diadaptkan obat TB paru selalu tersedia atau minimal sering tersedia di puskesmas. Sehingga tentunya tidak menyebabkan rendahnya tingkat peengobatan TB paru di Lagoa. Hasil ini sesuai dengan penelitian Hayati di Depok yang menyebutkan bahwa sebagian besar pasien merasa OAT selalu tersedia di Puskesmas. ${ }^{5}$ Ketersediaan obat serta mudahnya memperoleh obat di Puskesmas Lagoa sangat diperlukan bagi pasien TB paru dalam proses penyembuhan yang baik, sebab ketersediaan obat yang kurang baik dapat berpengaruh terhadap keberhasilan pengobatan pasien TB paru.

Selanjutnya peran PMO juga mempengaruhi rendahnya tingkat pengobatan penderita tuberkulosis paru di wilayah Lagoa. Persentase perilaku dukungan PMO terhadap pasien TB paru secara mayoritas adalah cukup mendukung. Hal ini artinya peran walaupun hasil yang didapat tidak terlalu dominan, tetapi tetap peran PMO sangat diperlukan dalam pengawasan pasien dalam mengkonsumsi obat. Hal ini tidak sejalan dengan hasil penelitian yang dilaksanakan Hayati bahwa mayoritas pasien menyatakan peran PMO termasuk dalam kategori yang mendukung upaya pengobatan penyakit TB paru. ${ }^{5}$

Pelayanan petugas yang merupakan salah satu dari faktor yang dapat juga mempengaruhi rendahnya tingkat pengobatan penderita tuberkulosis paru di wilayah Lagoa. Pada penelitian ini, didapatkan bahwa peran petugas TB di puskesmas yang dinilai antara lain adalah sikap petugas dalam memberikan pelayanan kesehatan kepada pasien TB paru, kesiapan dalam memberikan informasi tentang pentingnya untuk berobat secara teratur sehingga tuntas, pemberian informasi mengenai aturan minum obat secara benar dan gejala dari efek samping yang mungkin dialami oleh pasien, adannya kesediaan petugas saat mendengarkan berbagai keluhan dari pasien dan mampu memberikan solusinya, dan juga adanya peran petugas untuk melakukan penyuluhan kesehatan kepada seluruh keluarga pasien. 
Semua tindakan tersebut diatas adalah pelayanan kesehatan yang dilakukan oleh petugas TB dalam upaya untuk mendukung program penanggulangan penyakit TB paru. Hal ini tidak sesuai dengan hasil penelitian yang dilaksanakan oleh Hayati bahwa adanya peran dari petugas TB di Puskesmas masuk didalam kriteria mendukung upaya penanggulangan penyakit TB paru..$^{5}$

\section{SIMPULAN}

Didapatkan angka keberhasilan pengobatan TB paru di Puskesmas Lagoa pada tahun 2017 hanya mencapai 20,3\% dari target pencapaian yaitu $85 \%$. Mayoritas pasien TB paru adalah laki-laki dengan sebaran terbanyak pada rentang usia 25 sampai 34 tahun dan 45 sampai 54 tahun. Adanya hubungan bermakna antara jenis kelamin, ketersediaan obat, dukungan PMO, serta dukungan Petugas TB terhadap rendahnya angka keberhasilan pengobatan TB paru di Puskesmas Lagoa Tahun 2017. Jenis kelamin laki laki merupakan variabel yang memiliki hubungan paling besar dan bermakna dalam mempengaruhi rendahnya angka keberhasilan pengobatan TB paru.

\section{DAFTAR PUSTAKA}

1. Direktorat Jenderal Pengendalian Penyakit dan Penyehatan Lingkungan. Kementerian Kesehatan RI. =Strategi Nasional Pengendalian TB di Indonesia 2010-2014'. 2011. Diakses pada tanggal 15 Desember 2017.

http://www.searo.who.int/indonesia/topics/ tb/stranas_tb-2010-2014.pdf?ua=1

2. Direktorat Jenderal Pengendalian Penyakit dan Penyehatan Lingkungan, Kementerian Kesehatan RI. =Laporan Situasi Terkini Perkembangan Tuberkulosis di Indonesia Tahun 2011'.2012. Diakses pada tanggal $15 \quad$ Desember 2017. http://www.tbindonesia.or.id/opend ir/Dokumen/2011/IndonesiaReport2011. pdf

3. Puskesmas Kelurahan Lagoa. Laporan Tahunan Puskesmas Lagoa Tahun 2017, Puskesmas Kelurahan Lagoa, Jakarta. 2017

4. Kelurahan Lagoa, =Selayang Pandang Kelurahan Lagoa', diakses pada tanggal 16
Desember 2018. https://kelurahanlagoa.wordpress.com/te ntang_kelurahan_lagoa/

5. Hayati, A .Evaluasi Kepatuhan Berobat Penderita Tuberkulosis Paru Tahun 20102011 di Puskesmas Kecamatan Pancoran Mas Depok‘. 2011. Diakses pada tanggal $15 \quad$ Desember 2017. http://lib.ui.ac.id/file?file=digital/202053 93-S121-Evaluasi\%20kepatuhan.pdf

6. Maulidya, YN, Redjeki, ES, Fanani, E. Faktor yang Mempengaruhi Keberhasilan Pengobatan Tuberkulosis (TB) Paru pada Pasien Pasca Pengobatan di Puskesmas Dinoyo Kota Malang' 2017. Diakses pada tanggal 15 Juli 2018. http://journal2.um.ac.id/index.php/preve ntia/article/view/3191/1964

7. Harnanik .=Analisis Faktor-Faktor yang Mempengaruhi Keberhasilan Pengobatan TB Paru di Puskesmas Purwodadi II Kabupaten Grobogan'. 2014. Diakses pada tanggal 15 Juli 2018. http://digilib.unisayogya.ac.id/342/1/NA SKAH\%20PUBLIKASI.pdf

8. Hasan, N. Pengaruh Sosial Budaya dan Sikap Petugas Terhadap Keberhasilan Kesembuhan Pasien TB Paru di Puskesmas Semula Jadi Kecamatan Datuk Bandar Timur Kota Tanjung Balai'. 2018. Diakses pada tanggal 15 Juli 2018. http://repositori.usu.ac.id/bitstream/hand le/123456789/2420/131000033.pdf?sequ ence $=1 \&$ isAllowed $=\mathrm{y}$

9. Prayogo, AHE. _Faktor-faktor yang Mempengaruhi Kepatuhan Minum Obat Anti Tuberkulosis pada Pasien Tuberkulosis Paru di Puskesmas Pamulang Kota Tangerang Selatan Propinsi Banten Periode Januari 2013‘. 2013. diakses pada tanggal $15 \quad$ Juli 2018. http://repository.uinjkt.ac.id/dspace/bitstr eam/123456789/26334/1/Akhmad\%20H udan\%20Eka\%20Prayogo-fkik.pdf

10. Direktorat Jenderal Pengendalian Penyakit dan Penyehatan Lingkungan, Kementerian Kesehatan RI. Pedoman Nasional Pengendalian Tuberkulosis'. 2011. Diakses pada tanggal 9 Desember 2018.http://www.dokternida.rekansejawat. com/dokumen/DEPKESPedomanNasional 
Penanggulangan-

TBC2011.Dokternida.com.pdf

11. Badan Penelitian dan Pengembangan Kesehatan, Kementerian Kesehatan RI. Riskesdas: Laporan Riset Kesehatan Dasar Tahun 2013‘. 2013. Diakses pada tanggal 11Januari2018.http://www.depkes.go.id/re sources/download/general/Hasil\%20Risk esdas\%202013.pdf

12. Sudiantara, K, Wahyuni, NPS, Harini, IGA._Faktor-faktor yang Mempengaruhi Peningkatan Kasus TB Paru'. 2013. Diakses pada tanggal 13 Juli 2018. http://poltekkesdenpasar.ac.id/files/JUR NAL\%20GEMA\%20KEPERAWATAN/D ESEMBER\%202014/ARTIKEL\%20

Ketut\%20Sudiantara\%20dkk,.pdf

13. Rushadi, J,Kusumowardhani, E, Susanna, D, Wulandari, RA. Analisis Faktor Risiko Kejadian Tuberkulosis Paru BTA Positif di
Kota Sukabumi tahun 2014. 2014. Diakses pada tanggal 18 Juli 2018. http://www.lib.ui.ac.id/naskahringkas/2016 -06/S55983- Jeaneria\%20Rushadi

14. Rukmini \& Chatarina, UW._Faktorfaktor yang Berpengaruh terhadap Kejadian TB Paru Dewasa di Indonesia (Analisis Data Riset Kesehatan Dasar tahun 2010)‘. 2011, Diakses pada tanggal 18 Juli 2018. http://ejournal.litbang.depkes.go.id/ index.php/hsr/article/view/1369/2193

15. Azizah, R \& Inayah, Z. Faktor Dominan Ketidakberhasilan Pengobatan melalui Strategi DOTS pada Kasus Tuberkolosis BTA Positif di Puskesmas Pamolokan“. 2016. Diakses padatanggal15Juli2018. http://ejurnal.stikesinsanunggul.ac.id/we bstorage/jurna000000000001/b762c0d8e c0c295b14b156cf912df0a.pdf 